\title{
PEMBELAJARAN MEMBACA PEMAHAMAN \\ PADA SISWA KELAS V SD NEGERI 1 CIDEMPET KECAMATAN ARAHAN KABUPATEN INDRAMAYU
}

\author{
Muhafidin \\ STKIP Muhammadiyah Kuningan Jawa Barat \\ muhafidinghalbi@gmail.com
}

\begin{abstract}
This research is motivated by the ability of fifth grade students' reading comprehension is low, evidenced by the students do not understand and comprehend the content of reading, students had difficulty answering questions relating to the content of reading, as well as the average value of students still under KKM. This study aims to determine the effect of learning methods talk think write on the ability of reading comprehension folklore in class V SD Negeri 1 Cidempet of Arahan District of Indramayu Regency. This study was an experimental study. The population in this study were students of class V SD Negeri 1 Cidempet of Arahan District of Indramayu Regency totaling 22 students. The sampling technique used is total sampling where authors set into the sample population. So the study sample used is a fifth grade students of SD Negeri 1 Cidempet of Arahan District of Indramayu Regency totaling 20 students. Data collection techniques used is to write test. Data analysis techniques in this study is the normality test and test hypotheses (z test) is used to determine the effect of learning methods talk think write to the reading comprehension of folklore in class V SD Negeri 1 Cidempet of Arahan District of Indramayu Regency. Based on test results using a statistical hypothesis test obtained $Z$ hit $(7,458)>Z$ daf (2.35), then thank Hi means that there are significant learning method talk think write to the reading comprehension of folklore in class V SD Negeri 1 Cidempet of Arahan District of Indramayu Regency. The conclusion of this study is the application of learning methods talk think write on the ability of reading comprehension folklore in class V SD Negeri 1 Cidempet of Arahan District of Indramayu Regency. Suggestions in this study is teachers can implement a wide variety of learning methods in the implementation of learning so that students are active in studying and understanding the concepts being taught, and teachers should use teaching methods talk think write to improve reading comprehension folklore.
\end{abstract}

Keywords: Learning method talk think write, reading comprehension, folklore.

\section{PENDAHULUAN}

Pembelajaran membaca sangat penting bagi siswa, karena kemampuan membaca berkaitan dengan proses memahami dan memberi makna, memanfaatkan dengan tepat bahan bacaan yang dibaca untuk meningkatkan pengetahuan dan wawasan sehingga memiliki kemampuan lebih dari orang lain.

Membaca merupakan aktivitas pemrosesan kata-kata, konsep, informasi, dan gagasan-gagasan yang dikemukakan oleh pengarang yang berhubungan dengan pengetahuan dan pengalaman awal pembaca dengan mengamati simbol-simbol tulisan, menghubungkan kata-kata, membuat referensi dan evaluasi, dan menginterpretasikan apa yang diamati. Dengan demikian, pemahaman diperoleh apabila pembaca mempunyai pengetahuan atau pengalaman yang telah dimiliki sebelumnya dengan apa yang terdapat di dalam bacaan.

Membaca pemahaman yang merupakan jenis membaca dengan penuh pemahaman untuk menemukan gagasan/ide pokok yang 
terdapat dalam bacaan sehingga pembaca dapat memperoleh informasi dan memahami bacaan dengan baik (Subyantoro, 2011: 3). kemampuan membaca berkaitan dengan kemampuan pengenalan terhadap aksara serta tanda-tanda baca, korelasi aksara beserta tanda-tanda baca dengan unsur-unsur linguistik yang formal, keterampilan makna, pengenalan unsur-unsur linguistik, pengenalan hubungan atau korespondensi pola ejaan atau bunyi, ketepatan membaca bertaraf lambat, memahami pengertian sederhana, memahami signifikan atau makna, evaluasi atau penilaian isi dan bentuk, dan kecepatan membaca yang fleksibel (Zuchdi, 2008).

Menurut Suyatno (2008: 27), kemampuan membaca pemahaman adalah kemampuan memahami detail secara akurat, lengkap, dan kritis terhadap fakta, konsep, gagasan, pendapat, pengalaman, pesan, dan perasaan yang ada pada wacana tulis.

Berdasarkan aktivitas riil dan hasil observasi di SD Negeri 1 Cidempet Kecamatan Arahan Kabupaten Indramayu kemampuan membaca pemahaman siswa kelas V masih rendah, dibuktikan dengan siswa kurang mengerti dan memahami isi bacaan, siswa mengalami kesulitan menjawab pertanyaan berkaitan dengan isi bacaan, serta nilai rata-rata siswa masih berada di bawah KKM. Hal ini didukung data dari guru kelas berdasarkan hasil tes membaca pemahaman memperoleh rata-rata sebesar 59,05. Perolehan ini di bawah nilai kriteria ketuntasan minimal (KKM) yang telah ditetapkan sebesar 67.

Untuk meningkatkan kemampuan membaca pemahaman, penulis menerapkan pembelajaran Think Talk Write. Metode pembelajaran Think Talk Write adalah pembelajaraan yang menekankan keterlibatan siswa secara aktif dalam memahami permasalahan terlebih dahulu, kemudian terlibat secara aktif dalam diskusi kelompok, dan akhirnya menuliskan dengan bahasa sendiri hasil belajar yang diperolehnya (Yamin, 2008: 87).

Pembelajaran Think Talk Write dimulai dengan bagaimana siswa memikirkan penyelesaian suatu tugas atau masalah, kemudian diikuti dengan mengkomunikasikan hasil pemikirannya melalui forum diskusi, dan akhirnya melalui forum diskusi tersebut siswa dapat menuliskan kembali hasil pemikirannya. Aktivitas berpikir, berbicara, dan menulis adalah salah satu bentuk aktivitas belajar mengajar yang memberikan peluang kepada siswa untuk berpartisipasi aktif (Ansari, 2003: 29). Melalui aktivitas tersebut siswa dapat mengembangkan kemampuan berbahasa secara tepat, terutama saat menyampaikan ide-ide atau gagasan berkaitan dengan materi pelajaran.

Kelebihan metode pembelajaran Think Talk Write adalah mendidik siswa lebih mandiri, membentuk kerjasama tim, melatih berpikir, berbicara dan membuat catatan sendiri, lebih memberikan pengalaman pribadi, melatih siswa berani tampil, bertukar informasi antar kelompok/siswa, guru hanya sebagai pengarah dam pembimbing, siswa menjadi lebih aktif, dan meningkatkan pemahaman konsep siswa (Suyatno, 2009: 104)

Metode pembelajaran Think Talk Write, diharapkan mampu meningkatkan pemahaman dan hasil belajar siswa, melatih siswa belajar mandiri dalam berpikir, berbicara dan menulis terhadap konsep yang diajarkan, meningkatkan interaksi edukatif dan komunikasi yang baik diantara siswa dalam pembelajaran, mengembangkan 
kemampuan berpikir kritis dan kreatif terhadap konsep yang diajarkan, meningkatkan kemampuan mengemukakan pendapat terhadap konsep yang diajarkan, dan mengembangkan kemampuan memecahkan masalah pembelajaran.

Tujuan dari penelitian ini adalah mengetahui kemampuan membaca pemahaman cerita rakyat siswa kelas V SD Negeri 1 Cidempet Kecamatan Arahan Kabupaten Indramayu, mendeskripsikan penerapan metode pembelajaran think talk write dalam pembelajaran membaca di kelas V SD Negeri 1 Cidempet Kecamatan Arahan Kabupaten Indramayu, dan mengetahui pengaruh metode pembelajaran think talk write terhadap kemampuan membaca pemahaman cerita rakyat di kelas V SD Negeri 1 Cidempet Kecamatan Arahan Kabupaten Indramayu.

\section{METODE PENELITIAN}

Metode yang digunakan dalam penelitian ini adalah metode eksperimen dan desain penelitian yang digunakan dalam penelitian ini adalah non-equivalent Group pretestposttest design atau control group tidak menerima perlakuan.

Populasi pada penelitian ini adalah siswa kelas V SD Negeri 1 Cidempet Kecamatan Arahan Kabupaten Indramayu. Adapun sampel penelitian yaitu siswa kelas V SD Negeri 1 Cidempet Kecamatan Arahan Kabupaten Indramayu yang berjumlah 20 siswa.

Analisis data akan dilakukan menggunakan rumus $\mathrm{Z}$ dengan bantuan program SPSS 12. Selanjutnya hasil akan dideskripsikan secara berurutan mulai dari proses awal hingga proses akhir.

\section{HASIL DAN PEMBAHASAN}

\section{Tes Awal}

Data hasil pretest kemampuan membaca pemahaman kelas eksperimen sebelum penerapan metode pembelajaran think talk write memperoleh nilai terendah sebesar 50, nilai tertinggi sebesar 75 , dan memperoleh rata-rata sebesar 59,05. Perolehan ini berada di bawah nilai kriteria ketuntasan minimal (KKM) yang telah ditetapkan sebesar 67. Hal ini membuktikan bahwa hasil kemampuan membaca pemahaman cerita rakyat di kelas $\mathrm{V}$ SD Negeri 1 Cidempet Kecamatan Arahan Kabupaten Indramayu masih rendah.

Hasil pretest kemampuan membaca pemahaman siswa kelas eksperimen dapat dijadikan alat ukur untuk peningkatan kemampuan membaca pemahaman cerita rakyat di kelas V SD Negeri 1 Cidempet Kecamatan Arahan Kabupaten Indramayu. Kondisi kekurangmaksimalan nilai yang diperoleh siswa menggerakan hati peneliti untuk menggunakan metode pembelajaran think talk write.

\section{Tes Akhir}

Data hasil posttest kemampuan membaca pemahaman kelas eksperimen dengan menggunakan metode pembelajaran think talk write memperoleh nilai terendah sebesar 67 , nilai tertinggi sebesar 92, dan memperoleh rata-rata sebesar 80,32. Perolehan ini berada di atas nilai kriteria ketuntasan minimal (KKM) yang telah ditetapkan sebesar 67. Hal ini membuktikan bahwa penerapan metode pembelajaran think talk write dapat meningkatkan kemampuan membaca pemahaman cerita rakyat di kelas V SD Negeri 1 Cidempet Kecamatan Arahan Kabupaten Indramayu. 


\section{Profil Kemampuan Membaca Pemahaman}

\section{Siswa}

Berdasarkan hasil analisis data hasil pretest kemampuan membaca pemahaman kelas eksperimen sebelum penerapan metode pembelajaran think talk write memperoleh nilai terendah sebesar 50, nilai tertinggi sebesar 75 dan memperoleh rata-rata sebesar 59,05. Perolehan ini berada di bawah nilai kriteria ketuntasan minimal (KKM) yang telah ditetapkan sebesar 67. Hal ini membuktikan bahwa hasil kemampuan membaca pemahaman cerita rakyat di kelas $\mathrm{V}$ SD Negeri 1 Cidempet Kecamatan Arahan Kabupaten Indramayu masih rendah.

Berdasarkan hasil analisis data hasil posttest kemampuan membaca pemahaman kelas eksperimen dengan menggunakan metode pembelajaran think talk write memperoleh nilai terendah sebesar 67 , nilai tertinggi sebesar 92 dan memperoleh rata-rata sebesar 80,32. Perolehan ini berada di atas nilai kriteria ketuntasan minimal (KKM) yang telah ditetapkan sebesar 67. Hal ini membuktikan bahwa penerapan metode pembelajaran think talk write dapat meningkatkan kemampuan membaca pemahaman cerita rakyat di kelas V SD Negeri 1 Cidempet Kecamatan Arahan Kabupaten Indramayu.

Data tersebut menujukkan bahwa metode pembelajaran yang diterapkan sudah memenuhi kaidah standar sebagaimana disampaikan Nurgiyanto (2010: 38). Proses penerapan metode dan evaluasi dilakukan secara berkelanjutan dengan pendekatan proses (Sanjaya, 2010). Sehingga sangat memungki diperoleh hasil yang maksimal untuk membaca tingkat pencapaian siswa dalam pembelajaran.

\section{Pengaruh Metode}

Hasil pengujian statistik dengan menggunakan uji hipotesis diperoleh $\mathrm{Z}$ hit $(7,458)>\mathrm{Z}$ daf $(2,35)$, maka terima $\mathrm{H}_{\mathrm{i}}$ artinya bahwa terdapat pengaruh metode pembelajaran think talk write terhadap kemampuan membaca pemahaman cerita rakyat di kelas V SD Negeri 1 Cidempet Kecamatan Arahan Kabupaten Indramayu.

Berdasarkan hasil perhitungan statistik di atas hipotesis yang menyatakan terdapat pengaruh metode pembelajaran think talk write terhadap kemampuan membaca pemahaman cerita rakyat di kelas V SD Negeri 1 Cidempet Kecamatan Arahan Kabupaten Indramayu dapat diterima pada taraf kepercayaan $(\alpha) 0,05$.

\section{SIMPULAN}

Berdasarkan hasil pengolahan data dan pembahasan tentang pengaruh metode pembelajaran think talk write terhadap kemampuan membaca pemahaman cerita rakyat di kelas V SD Negeri 1 Cidempet Kecamatan Arahan Kabupaten Indramayu, maka penulis menarik kesimpulan sebagai berikut:

1) Data hasil pretest kemampuan membaca pemahaman kelas eksperimen sebelum penerapan metode pembelajaran think talk write memperoleh nilai terendah sebesar 50, nilai tertinggi sebesar 75 dan memperoleh rata-rata sebesar 59,05. Perolehan ini berada di bawah nilai kriteria ketuntasan minimal (KKM) yang telah ditetapkan sebesar 67. Dan data hasil posttest kemampuan membaca pemahaman kelas eksperimen dengan menggunakan metode pembelajaran think talk write memperoleh nilai terendah sebesar 67 , 
nilai tertinggi sebesar 92 dan memperoleh rata-rata sebesar 80,32 berada di atas nilai kriteria ketuntasan minimal (KKM) yang telah ditetapkan sebesar 67, hal ini membuktikan bahwa penerapan metode pembelajaran think talk write dapat meningkatkan kemampuan membaca pemahaman cerita rakyat di kelas V SD Negeri 1 Cidempet Kecamatan Arahan Kabupaten Indramayu;
2) Dari hasil pengujian statistik dengan menggunakan uji hipotesis diperoleh $\mathrm{Z}$ hit $(7,458)>Z$ daf $(2,35)$, maka terima $\mathrm{Hi}$ artinya bahwa terdapat pengaruh metode pembelajaran think talk write terhadap kemampuan membaca pemahaman cerita rakyat di kelas V SD Negeri 1 Cidempet Kecamatan Arahan Kabupaten Indramayu.

\section{DAFTAR PUSTAKA}

Ansari. 2003. Model-model Pembelajaran Inovatif. Semarang: UNNES.

Nurgiyantoro, Burhan. (2010). Penilaian dalam Pengajaran Bahasa dan Sastra. Yogyakarta: BPFE.

Sanjaya, Wina. 2010. Strategi Pembelajaran (Berorientasi Standar Proses Pendidikan). Jakarta : Kencana Prenada Media Group.

Subyantoro. 2011. Pengembangan Keterampilan Membaca Cepat. Yogyakarta: Graha Ilmu.

Suyatno. 2009. Menjelajah Pembelajaran Inovatif. Sidoarjo: Masmedia Buana Pustaka.

Suyatno. Hadi. Dkk. 2008. Indahnya Bahasa Dan Sastra Indonesia. Jakarta. Pusat Perbukuan Departemen Pendidikan Nasional.

Yamin, Martinis. 2008. Taktik Mengembangkan Kemampuan Individual Siswa. Jakarta: Gaung Persada Press.

Zuchdi, D. (2008). Strategi Meningkatkan Kemampuan Membaca: Peningkatan Komprehensi. Yogyakarta: UNY Press. 